\title{
Penyembuhan Gangguan Mental dengan Terapi Shirodhara dalam Pengobatan Ayurveda
}

\author{
Ni Luh Putu Novita Rosana Lestari ${ }^{1}$, Chieko Maeda ${ }^{2}$ \\ Universitas Hindu Negeri I Gusti Bagus Sugriwa Denpasar \\ e-mail: putunovita1@gmail.com ${ }^{1}$, balikobali@gmail.com ${ }^{2}$
}

Diterima tanggal 31 Juli 2021, diseleksi tanggal 12 Agustus 2021, dan disetujui tanggal 4 September 2021

\begin{abstract}
The complexity of modern life leads humans to adapt to create a healthy life behind the hustle and bustle of the world. Globalization and various advanced technologies require humans to be able to adapt to existing technology. The existence of competition from various sectors and the inability of humans to control themselves are the main causes of mental disorders which ultimately affect physical health. Mental disorder is a disease that can hinder a person's success in achieving his goals. If the symptoms of mental disorders such as stress, anxiety, etc. continue to be ignored, it will result in the emergence of chronic mental disorders. Humans try to prevent and treat symptoms and mental illness by utilizing pharmacological drugs that are instant healing, but if consumed in the long term it can have negative effects on body health. The alternative given by ancient ayurvedic medicine in dealing with mental disorders is the Shirodhara terapi. This terapi is believed to be able to provide a sensation of calm to the patient, reduce stress, anxiety and various health problems related to mental disorders. The use of warm herbal oil in this terapi may have no side effects.
\end{abstract}

Keywords: mental disorders; shirodhara; ayurveda

\section{ABSTRAK}

Kompleksitas kehidupan modern menggiring manusia untuk beradaptasi menciptakan kehidupan yang sehat di balik hiruk pikuknya dunia. Globalisasi dan berbagai teknologi canggih menuntut manusia untuk bisa menyesuaikan diri dengan teknologi yang ada. Adanya persaingan dari berbagai sektor dan kurang mampunya manusia dalam mengendalikan diri adalah hal utama penyebab gangguan mental yang pada akhirnya berimbas pada kesehatan fisik. Gangguan mental merupakan suatu penyakit yang dapat menghambat keberhasilan seseorang dalam mencapai tujuannya. Apabila gejala dari gangguan mental seperti stress, cemas, dan lain sebagainya terus dibiarkan maka berakibat pada munculnya gangguan mental yang bersifat kronis. Manusia berupaya untuk mencegah dan mengobati gejala maupun penyakit mental dengan memanfaatkan obat-obatan pharmakologi yang bersifat penyebuhan instan namun jika mengonsumsi dalam jangka panjang dapat mengakibatkan efek negatif bagi kesehatan tubuh. Alternatif yang diberikan oleh ilmu pengobatan kuno ayurveda dalam menangani masalah gangguan mental adalah dengan terapi Shirodhara. Terapi ini diyakini mampu memberikan sensasi ketenangan pada pasiennya, mengurangi stress, cemas dan berbagai masalah kesehatan yang berkaitan dengan gangguan mental. Pemanfaatan minyak herbal hangat pada terapi ini kemungkinan efek sampingnya tidak ada.

Kata kunci: gangguan mental; shirodhara; ayurveda 


\section{PENDAHULUAN}

Dalam kehidupan sehari-hari akan nampak berbagai gejala dalam diri manusia seperti rasa sedih, senang, kecewa, tertekan, takut dan lain sebagainya. Segala gejala tersebut tidak muncul sendiri, melainkan sebagai respon dari stimulus yang berasal dari lingkungan maupun respon yang diberikan oleh manusia terhadap lingkungan. Setiap manusia tidak bisa terlepas dari masalah dalam hidup. Kemampuan manusia dalam mengelola emosi dan pikiran saat menghadapi masalah berimbas pada kesehatan baik kesehatan fisik maupun mental. Hubungan antara gangguan fisik dengan gangguan mental manusia mulai diketahui sejak abad ke-19. Manusia bisa mengalami penyakit fisik karena diawali dengan penyakit mental (Rosyad, 2016). Gangguan mental adalah sesuatu yang berkaitan dengan kondisi kesehatan pikiran, suasana hati, perasaan dan perilaku seseorang. Dalam masyarakat gangguan mental bersumber dari beberapa faktor yaitu faktor internal seperti kurang mampu dalam menangani permasalahan dalam hidup yang mengakibatkan tekanan bathin, kecemasan akan suatu hal dan takut akan kehilangan. Faktor eksternal seperti tekanan dari luar, kurangnya perhatian dari orang terdekat, dan segala bentuk deskriminasi yang bersifat merendahkan yang bersumber dari lingkungan sekitar. Gangguan mental berdampak pada kurangnya kemampuan seseorang dalam memahami potensi diri sehingga menyebabkan produktifitas menurun pada penderita gangguan mental, yang pada akhirnya akan membebani keluarga, masyarakat maupun pemerintah. Selain itu seseorang yang mengalami gangguan mental tidak bisa mengatasi segala tekanan kehidupan meski yang bersifat normal. Karenanya gangguan mental tidak bisa dipandang sebagai suatu yang gampang untuk diatasi.

Terdapat 450 juta orang menderita gangguan mental diseluruh dunia (Ayuningtyas et al., 2018). Menurut WHO regional asia pasifik jumlah kasus gangguan depresi terbanyak di India yaitu 4,5\% dari jumlah populasi 56.675.969, kasus terendah ada di Maldives sebanyak 3,7\% dari jumlah populasi yaitu 12.739, dan di Indonesia sebanyak 3,7\% dari jumlah populasi yaitu 9.162.886 (WHO, 2017). Beberapa gejala umum yang dirasakan bagi penderita gangguan mental seperti kurangnya rasa percaya diri, rasa takut yang berlebihan dan perasaan tidak nyaman. Beberapa faktor yang bisa meningkatkan resiko gangguan mental diantaranya, faktor genetik, riwayat keluarga yang memiliki gangguan mental, stress berat, mengalami kejadian traumatis, penggunaan obat-obatan terlarang hingga kondisi medis tertentu seperti cedera otak berat, stroke dan gangguan tiroid (Adrian, 2020). Terdapat berbagai teknik pengobatan untuk menangani kasus gangguan mental seperti konseling bagi yang membutuhkan partner agar bisa mendiskusikan segala permasalahan yang sedang dialami, bagi yang memilih jalan instan bisa dengan penggunaan obat antidepresian sampai ditemukannya jalan alternatif bagi mereka yang dipercaya mampu memberikan efek menenangkan pada kondisi pikiran dan emosional yang sedang kacau. 
Jalan alternatif lain yang lebih efisien tanpa perlu melakukan gerak fisik secara langsung adalah dengan menggunakan terapi Shirodhara yaitu sebuah terapi yang berasal dari pengobatan Ayurveda. Sistem pengobatan ayurveda sudah ada sebelum dunia ini diciptakan mengedepankan pengobatan menggunakan tumbuh-tumbuhan sebagai hasil alam yang bersifat alami serta bersifat menyeluruh (holistic). Shirodhara merupakan salah satu dari sistem pengobatan ayurveda dengan memanfaatkan penggunaan minyak herbal untuk menciptakan sensasi menenangkan pada pasien yang mengalami gangguan mental dengan pusat terapi di sekitar kepala (ajna cakra). Saat seseorang mengalami gangguan mental seperti cemas, khawatir dan stress otak kiri akan lebih terangsang untuk berfikir, dalam hal ini seseorang berada dalam gelombang otak beta $(12 \mathrm{~Hz}-25$ $\mathrm{Hz}$ ) gelombang tinggi ini merangsang dikeluarkannya hormon kortisol dan neropinefrin yang berperan dalam suasana pikiran marah, cemas dan khawatir.

Terapi Shirodhara dilakukan dengan menuangkan minyak secara teratur ke bagian dahi dapat menyebabkan penurunan gelombang otak ke tahap rilaksasi yaitu gelombang otak alpha dimana seseorang mulai memasuki pikiran bawah sadar. Saat itulah otak akan memproduksi hormon serotonin dan endorphin yang berperan dalam menciptakan suasana bahagian, tenang dan nyaman. Hal ini menyebabkan aliran oksigen lebih banyak mengalir ke otak yang dapat membantu menstabilkan emosi seseorang. Sejalan dengan (Farisi, 2015) yang menyatakan bahwa gelombang alpha akan membuat imunitas tubuh meningkat, pembuluh darah terbuka lebar, detak jantung stabil dan kapasitas indra meningkat. Gangguan mental merupakan suatu penyakit yang dapat menghambat keberhasilan seseorang. Penyebabnya pun beragam dan cara penanganannya tidak bisa disepelekan. Terapi Shirodhara adalah alternatif untuk mengobati penyakit mental tentunya dengan tahapan dan membutuhkan waktu yang lama dalam mencapai kesembuhan total. Namun dari sejak dahulu sistem pengobatan ayurveda khususnya Shirodara telah dipercaya mampu menciptakan kondisi rileks pada pikiran yang nantinya berefek baik pada pengaturan emosional dan ketahanan dalam meghadapai masalah.

\section{PEMBAHASAN}

\subsection{Gangguan Mental}

Gangguan mental adalah kondisi kurang sejahteranya seorang individu yang tidak menyadari kemampuannya sendiri, tidak mampu mengatasi tekanan kehidupan yang normal, tidak dapat bekerja secara produktif dan tidak mampu memberikan kontribusi pada masyarakat. Gangguan mental muncul akibat adanya gangguan kesehatan mental hal ini memberikan dampak yang serius terhadap kepribadian dan perilaku seorang. Gangguan mental (mental illness) adalah kondisi kesehatan yang mempengaruhi pemikiran, perasaan, perilaku, suasana hati atau kombinasi 
diantaranya (Fadila, 2021). Gangguan mental bisa terjadi mulai dari gangguan yang bersifat ringan, sedang hingga parah, kondisi ini dapat terjadi pada siapapun yang berdampak buruk terhadap perilaku dan hubungan sosial penderita.

Gangguan mental secara umum ditemui seperti depresi, kecemasan, gangguan stress pasca trauma (PTSD), gangguan bipolar, gangguan obsesif kompulsif (OCD), psikosis postpartum depression yang hanya menyerang ibu setelah melahirkan. Menurut (Veronica, 2020) berikut penjelasan dari masing-masing jenis gangguan mental:

a. Depresi, merupakan gangguan mental yang paling sering dialami, gangguan mental ini ditandai dengan kesedihan yang terlalu lama hingga penderitanya merasa stress, putus asa, perasaan tidak berharga hingga berpengaruh pada kesehatan fisik yang sulit dideteksi oleh medis.

b. Kecemasan merupakan perasaan yang diawali karena tidak mampunya seseorang dalam mengendalikan pikiran dan perasaannya. Rasa cemas dapat berkembang menjadi rasa cemas yang sangat membebani dan dapat memburuk seiring berjalannya waktu. Gangguan ini meliputi gangguan obsesi kompulsif (OCD) dan fobia.

c. Gangguan stress pasca trauma (PTSD) merupakan gangguan kesehatan mental yang terjadi setelah seseorang melihat atau mengalami peristiwa traumatis. Peristiwa ini dapat berupa kejadian kejadian yang mengancam jiwa seperti bencana alam, kecelakaan, penganiayaan dan pelecehan sexual.

d. Gangguan bipolar adalah gangguan mental yang ditandai dengan perubahan suasana hati yang tidak normal perubahan yang terjadi cukup ekstrem dari perasaan hati sangat bahagia menjadi sangat sedih.

e. Gangguan obsesif kompulsif (OCD) merupakan gangguan berupa kecemasan dan ketakutan berlebihan apabila tidak melakukan suatu hal yang muncul dari pikiran berlebihan (obsesi) yang menimbulkan kompulsif atau perilaku repetitif.

f. Gangguan psikosis merupakan gangguan tipe mental disorder yang parah, menyebabkan persepsi seorang tidak normal dengan ditandai halusinasi dan delusi, skizofrenia adalah salah satu gangguan mental psikosis.

Gangguan mental dapat diklasifikasikan menjadi 11 kategori yaitu:

1. F00-F09: Organic, including symptomatic, mental disorders

2. F10-F19: Mental and behavioural disorders due to psychoactive substance use

3. F20-F29: Schizophrenia, schizotypal and delusional disorders

4. F30-F39: Mood (affective) disorders 
5. F40-F48: Neurotic, stress-related and somatoform disorders

6. F50-F59: Behavioural syndromes associated with physiological disturbances and physicial factors

7. F60-F69: Disorders of adult personality and behavior

8. F70-F79: Mental retardation

9. F80-F89: Disorders of psychological development

10. F90-F98: Behavioural and emotional disorders with onset usually occurring in childhood and adolescence

11. F99-F99: Unspectified mental disorders

Pembagian tersebut berdasarkan The ICD-10 edisi tahun 2010 (WHO, 2010) dan The ICD-10 Classification of Mental and Behavioural Disorder: clinical descriptions and diagnostic guidelines tahun 1992 dan (WHO, 1992). Sebelum seseorang divonis mengalami gangguan mental, sebelumnya akan diawali beberapa gejala seperti:

a. Delusi, paranoia atau halusinasi

b. Kehilangan kemampuan untuk berkonsentrasi

c. Ketidakmampuan mengatasi stress dan masalah sehari-hari

d. Muncul rasa takut, khawatir dan perasaan bersalah yang selalu menghantui

e. Mudah marah hingga berlebihan

f. Memiliki pikiran untuk menyakiti diri sendiri dan orang lain

g. Mengalami nyeri yang tidak dapat dijelaskan

h. Merasa bingung, pelupa mudah tersinggung, dan rasa kesal yang tidak biasa

i. Merasa putus asa, tidak berdaya, sedih dan tanpa harapan

j. Merokok, konsumsi alkohol hingga penggunaan obat terlarang

k. Mengalami lelah yang signifikan dan gangguan tidur

1. Tidak mampunya memahami situasi dan orang-orang

\subsection{Penyebab Gangguan Mental}

Gangguan mental merupakan salah satu dari bentuk gangguan jiwa, berdasarkan data riset kesehatan dasar kategori gangguan jiwa terdiri dari gangguan mental emosional (depresi dan kecemasan) serta gangguan jiwa berat atau psikosis (Kemenkes, 2013) bentuk gangguan jiwa lainnya yaitu postpartum depression dan bunuh diri atau suicide (WHO, 2015). Penyebab gangguan mental dapat berasal dari faktor biologis seperti pengaruh gen, gangguan fungsi otak, infeksi, cedera otak, gangguan nutrisi dan adanya suatu penyakit kronis serta disabilitas. Terdapat hubungan bermakna antara disabilitas dengan gangguan mental emosional hal ini karena 
seseorang yang mengalami disabilitas fisik dan disabilitas sosial akan dapat mempengaruhi kondisi kejiawaannya (Ayuningtyas et al., 2018). Begitupun dengan orang yang menderita satu penyakit kronis beresiko 2,6 kali lebih besar untuk menderita gangguan mental emosional, yang menderita dua penyakit kronis beresiko 4,6 kali dan yang menderita tiga penyakit kronis atau lebih beresiko 11 kali (Widakdo \& Besral, 2013). Faktor psikologis seperti rasa trauma, kehilangan sesuatu yang sangat dicintai, diabaikan dan sulit berhubungan dengan orang lain. Faktor lingkungan seperti kekerasan dalam lingkungan tempat tinggal.

\subsection{Terapi Shirodhara Dalam Penyembuhan Gangguan Mental}

\subsubsection{Pengobatan Ayurveda}

Setiap orang tentunya mendambakan hidup sehat terbebas dari segala jenis penyakit. Berbagai upaya dilakukan untuk menjaga kesehatan mulai dari pencegahan sampai pengobatan. Seiring perkembangan zaman orang-orang mulai beralih ke pengobatan alami seperti pengobatan ayurveda. Selain memiliki efek samping yang rendah pengobatan dengan bahan herbal dalam jangka panjang kemungkinan efek negatif yang timbul kecil dibandingkan obat-obatan sintetis. Ayurveda adalah ilmu yang mengulas mengenai cara hidup sehat dan dapat mencapai umur panjang. Ayurveda berasal dari kata "Ayu" dan "Vida" ayu berarti hidup, sehat dan panjang umur sedangkan vida berarti pengetahuan, jadi ayurveda adalah ilmu yang pengetahuan mengenai hidup sehat dan berumur panjang (Nala, 2001). Ayurveda sudah dikenal sejak dahulu sebagai ilmu pengobatan yang kompleks termasuk didalamnya meliputi pengetahuan tentang kesehatan mental, cara pemeriksaan, penegakkan diagnosis, pencegahan, pemeliharaan kesehatan, pengobatan penyakit, diet sehat dan berbagai cabang ilmu seperti anatomi, fisiologi, emriologi dan berbagai hal terkait dengan kesehatan dan umur panjang, hal ini membuat ilmu ayurveda memiliki kesamaan dengan ilmu kedokteran modern.

Ilmu kesehatan tradisional ayurveda masuk ke dalam kelompok upaveda di dalam veda smrti. Ilmu kesehatan kuno ayurveda diperkirakan sudah ada sekitar 500-600 tahun SM. Kitab ayurveda selain menguraikan tentang pengobatan, penyakit dan penyembuhan juga menguraikan berbagai hal yang berkaitan dengan kehidupan bagaimana cara mencapai umur panjang dan hidup dengan vitalitas yang baik sampai lanjut usia. Dalam ilmu ayurveda penyakit dapat muncul akibat ketidakseimbangan unsur-unsur yang ada dalam tubuh manusia seperti tri dosha (cairan humoral), sapta dhatu (tujuh jaringan) dan tri mala (tiga limbah buangan). Jika unsur tri dosha berada dalam keadaan seimbang serta unsur tri mala (limbah buangan) dapat dikeluarkan secara teratur maka sapta dhatu (jaringan tubuh) dapat menjalankan metabolismenya dengan baik. Apabila tri dosha 
keseimbangannya terganggu maka sistem ekskresi dalam tubuh juga ikut terganggu dan menyebabkan sapta dhatu (jaringan tubuh) tidak dapat melaksanakan fungsinya dengan baik.

Dalam (Nala, 2001) kitab Ayurveda terbagi menjadi delapan kitab berdasarkan cabang ilmu yang dipelajari, kedelapan cabang dari kitab ayurveda yaitu:

1. Kitab Kaya Chikitsa, kaya berarti kehidupan yang diakibatkan oleh kekuatan agni dan chikitsa berarti mengobati. Kaya chikitsa berarti ilmu yang mengobati penyakit yang diakibatkan oleh gangguan unsur agni dalam tubuh. Kaya chikitsa dalam dunia kedokteran modern disamakan dengan pengobatan penyakit dalam. Unsur agni dalam hal ini diartikan sebagai enzim dalam tubuh, sebelum terjadi gangguan pada unsur agni terlebih dulu jaringan tubuh (dhatu) yang mengalami gangguan.

2. Kitab Salya Tantra (Salya Chikitsa), cabang Ayurveda yang mempelajari tentang tatacara pengobatan pada luka yang terkena benda tajam. Dalam ilmu kedokteran modern disamakan dengan ilmu bedah. Tatacara pengobatannya meliputi pembedahan, pemotongan, pelarutan dan sebagainya.

3. Kitab Salakya (Urdvanga Chikitsa), dalam ilmu pengobatan modern dikenal dengan dokter ahli THT, dalam Ayurveda cabang tersebut dipelajari dalam Urdvanga Chikitsa yaitu ilmu yang mempelajari mengenai pengobatan penyakit khusus dari leher sampai kepala seperti indera mata, telinga, hidung, tenggorokan dan mulut.

4. Kitab Kaumara Bhrtya (Bala Chikitsa), yaitu menguraikan mengenai tata cara pengobatan pada anak, dalam dunia kedokteran modern dapat disamakan dengan dokter spesialis anak (paediatri). Selain itu juga mempelajari mengenai pengobatan dan perawatan pada ibu hamil dan menyusui.

5. Kitab Agada Tantra (Damshtra Chikitsa), yaitu ilmu yang mempelajari mengenai cara pengobatan dan tata cara mengidentifikasi racun baik yang berasal dari tumbuh-tuumbuhan, binatang maupun benda mati. Dalam ilmu kedokteran modern dikenal dengan ilmu toksikologi.

6. Kitab Vajikarana Tantra (Vrishya Chikitsa), mempelajari tentang fertilitas, yang meliputi tata cara pengobatan untuk kesuburan pria dan wanita. Dalam illmu kedokteran modern dikenal dengan ilmu pengetahuan seksual (andrologi).

7. Kitab Rasayana Tantra (Jara Chikitsa), yaitu mempelajari tentang tata cara agar manusia tetap awet muda yang meliputi tata cara pemeliharaan tubuh, pencegahan penuaan pada kulit, rambut, tata cara pemeliharaan indera, organ serta cara peningkatan intelektual dengan tujuan agar tetap awet muda. Hal ini dilakukan dengan cara mengonsumsi makanan sehat (ahara), dengan pengobatan khusus (ausadhi) dan dengan perlakuan khusus (vihara). 
8. Kitab Graha Chikitsa, yaitu ilmu yang mempelajari mengenai kejiwaan, dalam ilmu kedokteran modern dikenal dengan istilah psikiatri dan psikologi. Ilmu ini berisi tentang tata cara mengobati dan pencegahan penyakit mental.

Sistem pengobatan ayurveda memiliki kemiripan dengan ilmu pengobatan modern, ayurveda adalah ilmu yang bersifat holistik. Ilmu pengobatan ayurveda dalam penegakkan diagnosa melalui tahapan yang berbeda dengan ilmu pengobatan modern. Ayurveda memandang setiap tubuh manusia berbeda sesuai dengan unsur yang mendominasi, sehingga penanganan suatu penyakit yang sama pada masing-masing orang akan berbeda dalam artian ayurveda lebih bersifat subjektif, sedangkan dalam dunia kedokteran modern suatu penyakit yang sama pada setiap orang akan mendapat penanganan yang sama, cenderung memandang setiap individu itu sama berdasarkan anatomi dan fisiologinya dalam artian cenderung objektif.

\subsubsection{Shirodhara}

Gangguan mental melibatkan pikiran dan tubuh, penyakit mental dapat terjadi karena diawali oleh penyakit fisik, begitupun sebaliknya. Sebagian besar masyarakat mengonsumsi obatobatan pharmakologi sebagai pencegahan sekaligus pengobatan apabila terdapat eksistensi gangguan mental. Hal itu semata-mata untuk memperoleh suatu ketenangan dalam diri. Gangguan mental dapat dialami oleh siapapun dan gangguan ini tentu ada obatnya. Alternatif pengobatan dan pencegahan dari gangguan mental salah satunya adalah melalui terapi Shirodhara, yaitu sebuah teknik pengobatan yang berasal dari ilmu ayurveda yang merupakan ilmu pengobatan tradisional India, yang juga mempunyai pengaruh besar terhadap pengobatan kedokteran modern. Shirodhara terdiri atas dua kata yaitu shiro yang berarti kepala dan dhara mengandung makna aliran (Sharma, 2020). Terapi Shirodhara memberikan keadaan kesadaran yang relaks dan menghasilkan keseimbangan antara tubuh dan pikiran yang dinamis sehingga mampu memunculkan suasana hati yang tenang.

Shirodhara merupakan bentuk terapi Ayurveda dengan cara menuangkan cairan yang berupa minyak ke dahi. Shirodhara juga disebut sebagai prosedur pachakarma Ayurveda klasik yang sudah popular di seluruh dunia karena efek penghilang stresnya (Sharma, 2020). Beberapa penelitian terkait penggunaan terapi Shirodhara juga menyimpulkan bahwa terapi ini mampu menghilangkan beberapa gangguan kesehatan seperti insomnia, dengan menggunakan cairan berupa minyak yang terbuat dari daun brahmi atau pegagan (Vinjamury et al., 2014) hal ini tentunya memberikan manfaat yang bagus untuk pasien karena penggunaan bahan-bahan herbal dapat mengurangi efek buruk dari penggunaan obat farmakologi. Terapi Shirodhara disebut juga dengan pijat mata ketiga atau pijat india. Dikatakan sebagai pijat mata ketiga karena melibatkan 
penuangan minyak secara teratur pada bagian dahi tepat di posisi cakra ajna (mata ketiga). Terapi Shirodhara memiliki efek yang baik bagi kesehatan diantaranya dapat mengurangi keglisahan, cemas, stress, depresi, rasa takut, sakit kepala, kelelahan serta dapat membantu meningkatkan suasana hati menjadi baik. Hal ini dikarenakan ketika seseorang mengalami gangguan pada kesehatan terutama yang berkaitan dengan mental dimana kondisi gelombang otak manusia adalah beta $(12 \mathrm{~Hz}-25 \mathrm{~Hz})$ gelombang tinggi ini merangsang dikeluarkannya hormon kortisol dan neropinefrin yang berperan dalam suasana pikiran marah, cemas dan khawatir, ketika minyak dituangkan ke dahi menyebabkan penurunan gelombang otak ke tahap rilaksasi yaitu gelombang otak alpha dimana seseorang mulai memasuki pikiran bawah sadar. saat itulah otak akan memproduksi hormon serotonin dan endorphin yang berperan dalam menciptakan suasana bahagian, tenang dan nyaman. Setelah otak tenang maka oksigen akan mengalir lancar ke otak, ha ini dapat membantu menstabilkan emosi seseorang dan dapat membantu menurunkan gejala gangguan mental.

\subsubsection{Terapi Shirodhara}

Gangguan psikis memang memberikan dampak negatif bagi penderitanya, gangguan mental seperti stress dapat membuat tubuh memproduksi hormon adrenalin dan kortisol dalam tubuh melonjak, jika hal ini terus dibiarkan maka dapat berpengaruh pada kesehatan fisik seseorang. Terapi Shirodhara yang ditawarkan sebagai jalan alternatif dimasa sekarang sebagai terapi untuk mencegah dan menghilangkan gangguan mental terbukti secara klinis berhasil dengan sifat kompleksnya yang memberikan efek menenangkan pikiran dan membuat tubuh rileks. Dalam ayurveda disebutkan bahwa penyakit yang muncul baik penyakit fisik maupun mental dapat terjadi akibat ketidakseimbangan unsur-unsur di dalam tubuh seperti unsur tri dosha yaitu kapha, pitta dan vata. Shirodhara dapat membangun kembali integritas antara sub jenis dosha ini sehingga membantu dalam pengelolaan pikiran (Sreeja \& Sadanandam, 2016). Shirodhara adalah teknik penyembuhan penting ayurveda yang memiliki efek neuro-imuno-fisio-psikologis pada tubuh manusia (Rajan et al., 2021)

Terapi Shirodhara memanfaatkan penggunaan minyak herbal seperti minyak wijen, minyak kelapa, minyak daun brami dan sebagainya. Minyak herbal tersebut tentunya memiliki khasiat tersendiri berdasarkan kandungan zat di dalamnya. Penggunaan minyak yang berbeda dilakukan pada kondisi tubuh pasien dengan unsur yang mendominasi tubuh berdasarkan unsur tri dosha (kapha, pitta dan vata). Terapi Shirodhara memerlukan beberapa alat dan bahan seperti minyak herbal yang masih dalam kondisi hangat, bejana, meja, handuk, bejana kecil, sumbu, tempurung kelapa dengan lubang ditengahnya kemudian dibuat lubang di tengah bejana sebagai 
aliran minyak. Susunan alat Shirodhara digantung di atas dahi orang yang telentang dengan tinggi 3 inci. Saat terapi berlangsung mata pasien ditutup dengan kain katun yang dililitkan secara horizontal di sekitar kepala kemudian minyak herbal hangat dengan suhu tidak boleh melebihi 25 derajad celcius dialirkan secara stabil di dahi dengan lama terapi 45 sampai 50 menit. Terapi ini dapat dilakukan setiap hari selama 7 sampai 14 hari sesuai dengan sifat penyakitnya. Terapi ini menginduksi keadaan kesadaran yang rileks dan menghasilkan keseimbangan psikosomatik yang dinamis. Penelitian (Dhuri et al., 2013) mengatakan bahwa Shirodhara mengarah pada keadaan ketenangan waspada yang mirip dengan respon rileksasi yang diamati dalam meditasi. Manfaat klinis yang diamati dengan Shirodhara dalam neurosis kecemasan, hipertensi dan stress akibat penyakit degeneratif kronis dapat dimediasi melalui efek fisiologis adaptif ini (Dhuri et al., 2013). Pemberian terapi Shirodhara dikatakan memiliki manfaat yang lebih nyata dalam membantu mengurangi tekanan sistolik dan diastolik pada hipertensi (Kundu et al., 2010). Selain itu dalam penelitian dengan pasien yang menderita insomnia, kehilangan konsentrasi dan gejala mood iritabel, diberikan terapi Shirodhara selama 14 hari secara terus menerus menunjukkan peningkatan kesembuhan secara signifikan dan tidak ada efek samping yang ditemui dengan menggunakan terapi Shirodhara (Rajan et al., 2021). Shirodhara sebagai terapi pengobatan unik Ayurveda memanfaatkan penggunaan minyak herbal hangat pada dahi dapat membantu meremajakan sistem saraf, melepaskan emosi, membuka saluran halus dan memunculkan kebahagiaan ke seluruh pikiran dan tubuh (Dornala \& Snehalatha, 2014).

\section{SIMPULAN}

Dinamisnya kehidupan seiring perkembangan teknologi yang kian hari memaksa manusia untuk bisa menyesuaikan diri dengan teknologi yang ada. Kompleksitas kehidupan modern menggiring manusia untuk beradaptasi menciptakan kehidupan yang sehat dibalik hiruk pikuknya dunia. Saat ini persaingan dalam berbagai sektor menimbulkan ketegangan dan tekanan emosional dalam diri masing-masing individu yang tidak mampu untuk mengendalikan diri. hal ini berimbas pada kondisi kesehatan fisik dan mental seseorang. jika kondisi tertekan dan berbagai suasana hati yang negatif terus dibiarkan maka dapat mengakibatkan gangguan mental yang cukup serius. Berbagai upaya dilakukan oleh manusia untuk tetap bisa sehat terbebas dari berbagai penyakit salah satunya adalah dengan memanfaatkan obat-obatan pharmakologi. Selain itu dalam dunia pengobatan tradisional ayurveda dikenal dengan sistem pengobatannya yang menyeluruh. Sistem pengobatan ayurveda memiliki kemiripan dengan ilmu pengobatan modern. Alternatif yang ditawarkan oleh ilmu kesehatan tradisional ayurveda dalam mengatasi gangguan kesehatan khususnya gangguan mental adalah dengan memanfaatkan terapi Shirodhara. Selain bermanfaat 
untuk meredakan gejala stress, cemas dan gejala gangguan mental lainnya Shirodhara hampir tidak memiliki efek samping jika sering dilakukan. Pemanfaatan minyak herbal hangat yang dituangkan secara teratur ke dahi pasien dapat memberikan sensasi menenangkan sehingga dapat memicu otak untuk memproduksi hormon endorfin yang bertugas dalam menciptakan suasana hati yang baik. Jadi terapi Shirodhara sangat dianjurkan untuk seseorang dengan gejala gangguan mental ringan maupun berat dalam pencegahan maupun pengobatan karena manfaatnya yang luar biasa.

\section{DAFTAR PUSTAKA}

Adrian, K. (2020). Macam-Macam Gangguan Jiwa Yang Umum Terjadi. Alodokter. Ayuningtyas, D., Misnaniarti, \& Rahyani, M. (2018). Analisis Situasi Kesehatan Mental Pada Masyarakat Di Indonesia Dan Strategi Penanggulangannya. Jurnal Ilmu Kesehatan Masyarakat, $9(1)$.

Dhuri, K. D., Bodhe, P. V, \& Vaidya, A. B. (2013). Shirodhara: A Psychophysiological Profile in Healthy Volunteers. Jurnal Ayurveda and Integrative Medicine, 4(1), 40.

Dornala, S. N., \& Snehalatha. (2014). Multidimensional Effects of Shirodhara on Psychosomatic Axis in The Management of Psycho-Physiological Disorders. International Journal of Ayurveda and Pharma Research, 2(4), 32-40.

Fadila, I. (2021). Mental Illness (Gangguan Mental). Hello Sehat.

Farisi, A. (2015). Mengenal GelombangOtak Dan Cara Kerja Pikiran (Bagian 1). Kompasiana. Kemenkes. (2013). Laporan Riset Kesehatan Dasar. Kementerian Kesehatan RI.

Kundu, C., Shukla, V., Santwani, M., \& Bhatt, N. (2010). No TitleThe Role of Psychic Factors in Pathogenesis of Essential Hypertension and Its Management by Shirodhara and Sarpagandha Vati. Ayurveda, 31(4), 436.

Nala, N. (2001). Ayurveda Ilmu Kedokteran Hindu. Upada Sastra.

Rajan, S., Shamkuwar, M. K., \& Tanwar, A. K. (2021). Impact of Shirodhara on Biological Markers of Stress: A Case Study. Journal of Ayurveda and Integrative Medicine, 12(1), $178-181$.

Rosyad, R. (2016). Pengaruh Agama Terhadap Kesehatan Mental. UIN Sunan Gunung Jati, 1 No 1 .

Sharma, S. (2020). Effect of Shirodhara in Psychosomatic Diseases (Manas Rogas). International Journal of Science and Research, 9(4), 366-369.

Sreeja, A., \& Sadanandam, C. (2016). Role of Shirodhara in Management of Stress. International Journal of Advanced Research, 1367-1371. 
https://doi.org/10.21474/IJAR01/1338

Veronica, D. (2020). Macam-Macam Gangguan Jiwa yang Umum Terjadi. 9 Juni 2020.

Vinjamury, S., Vinjamury, M., Martirosian, C., \& Miller, J. (2014). Ayurvedic Therapy (Shirodhara) for Insomnia : A Case Series. Sagr Journal, 3(1), 75-80.

https://doi.org/10.7453/gahmj.2012.086

WHO. (1992). The ICD-10 Classification of Mental and Behavioural Disorders: clinical descriptions and diagnostic guidelines. World Health Organization1992.

WHO. (2010). International Statistical Classification of Diseases and Related Health Problems, 10th Revision. World Health Organization 2010.

WHO. (2015). Global Mental Health 2015. World Health Organization.

WHO. (2017). Depression And Other Common Mental Disorders. In Global Health Estimates. Geneva. World Health Organization.

Widakdo, G., \& Besral. (2013). Efek Penyakit Kronis Terhadap Gangguan Mental Emosional. Jurnal Kesehatan Masyarakat, 7 (7), 309-316. 